\title{
Mechanical factors and vitamin $D$ deficiency in schoolchildren with low back pain: biochemical and cross-sectional survey analysis
}

This article was published in the following Dove Press journal:

Journal of Pain Research

II April 2017

Number of times this article has been viewed

\author{
Ahmad H Alghadir ${ }^{\prime}$ \\ Sami A Gabr ${ }^{1,2}$ \\ Einas S Al-Eisa' \\ 'Rehabilitation Research Chair, \\ College of Applied Medical Sciences, \\ King Saud University, Riyadh, Kingdom \\ of Saudi Arabia; ${ }^{2}$ Department of \\ Anatomy, Faculty of Medicine, \\ Mansoura University, Mansoura, Egypt
}

Objective: This study was designed to evaluate the role of vitamin D, muscle fatigue biomarkers, and mechanical factors in the progression of low back pain (LBP) in schoolchildren.

Background: Children and adolescents frequently suffer from LBP with no clear clinical causes, and $>71 \%$ of schoolchildren aged $12-17$ years will show at least one episode of LBP.

Materials and methods: A total of 250 schoolchildren aged 12-16 years were randomly enrolled in this study. For all schoolchildren height, weight, percentage of daily sun exposure and and areas of skin exposed to sun, method of carrying the bag, and bag weight and type were recorded over a typical school week. Pain scores, physical activity (PA), LBP, serum vitamin $25(\mathrm{OH}) \mathrm{D}$ level, serum bone-specific alkaline phosphatase, creatine kinase (CK), and lactate dehydrogenase (LDH) activities and calcium (Ca) concentrations were estimated using prevalidated Pain Rating Scale, modified Oswestry Low Back Pain Disability Questionnaire, short-form PA questionnaire, and colorimetric and immunoassay techniques.

Results: During the period of October 2013-May 2014, LBP was estimated in 52.2\% of the schoolchildren. It was classified into moderate (34\%) and severe (18\%). Girls showed a higher LBP (36\%) compared with boys (24\%). In schoolchildren with moderate and severe LBP significantly higher $(P=0.01)$ body mass index, waist, hip, and waist-to-hip ratio measurements were observed compared with normal schoolchildren. LBP significantly correlated with less sun exposure, lower PA, sedentary activity (TV/computer use), and overloaded school bags. In addition, schoolchildren with severe LBP showed lower levels of vitamin 25(OH)D and $\mathrm{Ca}$ and higher levels of $\mathrm{CK}$, LDH, and serum bone-specific alkaline phosphatase compared with moderate and healthy schoolchildren. Stepwise regression analysis revealed that age, gender, demographic parameters, $\mathrm{PA}$, vitamin $\mathrm{D}$ levels, $\mathrm{Ca}$, $\mathrm{CK}$, and LDH associated with $\sim 56.8 \%-86.7 \%$ of the incidence of LBP among schoolchildren.

Conclusion: In children and adolescents, LBP was shown to be linked with limited sun exposure, inadequate vitamin D diets, adiposity, lower PA, sedentary lifestyles, vitamin $25(\mathrm{OH}) \mathrm{D}$ deficiency, and lower levels of $\mathrm{Ca}, \mathrm{CK}$, and $\mathrm{LDH}$.

Keywords: low back pain, LBP, mechanical factors, 25(OH)D concentrations, muscle pain, physical activity

\section{Introduction}

Approximately $60 \%-80 \%$ of children and adolescents frequently suffer from low back pain (LBP) without clear clinical causes. ${ }^{1}$ Similar to adults, the prevalence rates of LBP in children and adolescents increase by the age of $14-17$ years, and $>71 \%$ of schoolchildren show at least an obvious LBP. ${ }^{2-6}$

In a meta-analysis study, a higher prevalence rate of LBP was reported in children and adolescents compared with old population and a higher recurrence of LBP and the
Rehabilitation Research Chair, College of Applied Medical Sciences, King Saud University, PO Box 10219, Riyadh II433, Kingdom of Saudi Arabia

Tel +966562060018

Fax+966 I 469854I

Email sgabr@ksu.edu.sa 
tendency to reappear with a greater intensity were observed among children. ${ }^{7-9}$ Previously, it was reported that a family history, an accelerated growth rate, physical activity (PA) status, smoking, and some psychological traits such as depression seem to increase the risk of LBP in children. ${ }^{9-11}$ LBP showed lower or no clear association with most biological and anthropometric parameters such as body length, weight, body mass index (BMI), length of the trunk, and vertebral column mobility. ${ }^{11-15}$ Moreover, little is known regarding the association between LBP and general muscle strength, especially hip flexor muscle flexibility. ${ }^{15-18}$

Mechanical and physical factors comprise most of the causative mechanisms for LBP among schoolchildren of both genders. ${ }^{19}$ Most studies showed that schoolchildren carry more weights that exceed the body weight/load ratio limits proposed for adults; ${ }^{20}$ these backpack loads were significantly associated with LBP in children. ${ }^{21-23}$ For the best function of the muscles and nervous system throughout the life of a human body, vitamin $\mathrm{D}$ is essential for the development and maintenance of the musculoskeletal system. ${ }^{24}$ Sufficient serum levels of vitamin D, calcium $(\mathrm{Ca})$, and phosphorus (P) are required for better bone health and muscle performance. ${ }^{25-27}$ Higher rates of vitamin D deficiency were shown to correlate with various nonspecific musculoskeletal pains, including $\mathrm{LBP}^{28,29}$ The deficiency in vitamin $\mathrm{D}$ may be related to poor PA, ${ }^{30}$ adiposity, minimal sun exposure, ${ }^{31-33}$ insufficient dietary intake, or impairments in metabolic activation of the vitamin. ${ }^{34-36}$

In adolescents, especially girls, poor muscle performance was reported to be linked with physical inability and vitamin D deficiency, whereas both power and force of skeletal muscles were greatly affected by vitamin D levels. ${ }^{36}$ These factors may produce a significant myopathy that leads to muscle fatigue and reduced motivation to daily activities. ${ }^{30,33,37}$

In addition, it was reported that muscle-related pain comprises most of back pain present in adolescents, whereas it is localized to paraspinal muscles of the thoracic or lumbar area. ${ }^{38,39}$ This type of pain is commonly related to overuse, mechanical loading, or carrying a heavy rucksack, ${ }^{40,41}$ and excessive fatigability was shown to be a predictor of a first episode of $\mathrm{LBP}^{42}$ It was estimated that the measurements of creatine kinase $(\mathrm{CK})$ and $\mathrm{Ca}$, along with lactate dehydrogenase (LDH) activity, may allow earlier detection of muscle injury. ${ }^{43-45}$ In addition, serum bone-specific alkaline phosphatase (sBAP) as one of bone turnover markers was shown to be correlated with serum levels of vitamin $25(\mathrm{OH})$ $\mathrm{D}$ and may have a potential role in evaluating the status of LBP in both children and adolescents. ${ }^{46,47}$ These biomarkers may clearly help in evaluating the pivotal role of vitamin D status and muscle-related pain in the occurrence of LBP among children and adolescents.

Until now, no more studies have been conducted to assess the effects of vitamin D deficiency, muscle performance, and mechanical factors on LBP among schoolchildren. Hence, the current study was designed to evaluate the roles of mechanical factors, vitamin D levels, and muscle performance, which were estimated by measuring the levels of CK, Ca, and sBAP, in the progression of LBP in schoolchildren.

\section{Materials and methods Schoolchildren}

A total of 300 schoolchildren aged 12-16 years were randomly invited to participate in this cross-sectional survey study from eight secondary schools chosen from different places in Mansoura, Egypt. The data were collected during the period of October 2013-May 2014 to match with Egypt school year season. Only 250 schoolchildren who had no serious acute or chronic diseases, malabsorption, physical disability, or musculoskeletal disorders were included in this study. Schoolchildren who reported using medications known to affect body weight (such as steroids) and those taking $\mathrm{Ca}$, vitamin $\mathrm{D}$, or multivitamin supplements were excluded from the study. All schoolchildren were instructed not to change their normal eating habits during the study period. Prior to data collection, written informed consent was obtained from the parents of all participating schoolchildren and the study was reviewed and approved by the ethical committee of the Rehabilitation Research Chair, King Saud University, Riyadh, Kingdom of Saudi Arabia, under the file number ID: RRC-2013-018.

\section{Assessment of LBP}

A prevalidated Pain Rating Scale of 0-10 and a modified Oswestry Low Back Pain Disability Questionnaire (OSW) were used to evaluate LBP and pain scores among all schoolchildren as previously reported. ${ }^{48-50}$ LBP disability was quantified during school year season from October 2013 to May 2014 using the OSW scale (a 10-item scale) with scores ranging from 0 to 100; higher scores indicated greater disability. According to the OSW scale, LBP disability scores were interpreted as minimal ( $0 \%-20 \%)$, moderate $(20 \%-40 \%)$, severe $(41 \%-60 \%)$, crippled $(61 \%-80 \%)$, and bed-bound or exaggerating people $(81 \%-100 \%){ }^{48,49}$

\section{Assessment of mechanical factors}

BMI, PA, part-time jobs involving heavy lifting, active and passive transports, and school bag weight were assessed 
as mechanical factors in all schoolchildren as previously reported. ${ }^{51}$

\section{Estimation of BMI}

Anthropometric measurements, such as height and weight measurements, were evaluated for all schoolchildren using a tape measure and calibrated Salter Electronic Scales (Digital Pearson Scale; ADAM Equipment Inc., Columbia, MD, USA) with a standardized procedure. BMI was calculated as the ratio of weight $(\mathrm{kg})$ to height $(\mathrm{m})$ squared and identified according to cutoff values previously proposed. ${ }^{52}$

\section{School bag weight}

Diary information relating to the type of school bag, bag weight measurement using spring scales, the method of carrying the bag, and part-time jobs involving heavy lifting was recorded over a typical school week. In addition, percentage of body weight carried by each schoolchild was calculated by dividing the average daily bag weight (total bag weight for 5 days/number of days) by the weight of the child and transforming the data into quintiles. ${ }^{51,52}$ Although, the correlation between backpacks and back pain is not clear, previous guidelines recommend that normal backpacks should not exceed $10 \%-20 \%$ of the child's body weight. ${ }^{53,54}$

\section{Physical and sedentary activity levels}

Physical and sedentary activity levels of the schoolchildren were assessed using prevalidated questionnaires. ${ }^{51}$ The frequencies and duration of sporting activities during the past week and sedentary activities, such as the amount of time spent watching television and the computer during the past day and seated body positions, were estimated for each schoolchild as reported in the literature. ${ }^{51}$

\section{Biochemical analysis}

Serum vitamin 25(OH)D level, CK and LDH activities, and $\mathrm{Ca}$ and sBAP concentrations were estimated in serum freshly separated from blood samples of each schoolchild as mentioned previously. ${ }^{55,56}$ Vitamin $25(\mathrm{OH}) \mathrm{D}$ levels were estimated in serum samples using immunoassay kits (IDS, Tyne \& Wear, UK). Serum CK and LDH activities were measured using available enzymatic assays (Granutest 15; EMD Millipore, Billerica, MA, USA) and ultraviolet assays (Randox Laboratories Ltd., Antrim, UK). Colorimetric assays using Cobas Integra ${ }^{\circledR}$ analyzer and available kits (Hoffmann-La Roche Ltd., Basel, Switzerland) were used to determine $\mathrm{Ca}$ levels in serum. sBAP concentrations (U/L) were measured in serum using the MicroVue BAP immunoenzymometric assay (Quidel Corporation, San Diego, CA, USA). ${ }^{55,56}$

\section{Duration of sun exposure and vitamin D status in diets}

Daily exposure to sun during the previous month in all schoolchildren was estimated as the average number of hours per day the schoolchildren were exposed to sun; in addition, areas of skin exposed, the usual material (natural or synthetic) of clothes, and color (black or colored) of clothes were evaluated in all schoolchildren. Based on the checklist of food consumption of each schoolchildren, vitamin D was classified into two types: low or adequate..$^{57,58}$

\section{Statistical analysis}

The collected data were analyzed statistically using SPSS version 16 (SPSS, Chicago, IL, USA). Quantitative and qualitative variables were expressed as mean \pm standard deviation and number (percentage), respectively. Student's $t$-test, oneway analysis of variance, and Mann-Whitney $U$-test were used to estimate correlation analysis of the studied variables. Stepwise linear regression analysis was done to perform the correlation between vitamin D, LBP scores, and other studied parameters ${ }^{55} P$-values were significant at $P<0.05$.

\section{Results}

In relation to LBP-OSW scores, $\sim 48 \%(\mathrm{n}=120)$ of the study population had a lower OWS score $(0 \%-20 \%)$ with a mean score of 9.8; they were diagnosed as with minimal or no LBP. A total of $52 \%$ of the study population $(n=130)$ had higher OWS mean scores; they were categorized into those with moderate LBP (score $21 \%-40 \%$; $n=85 ; 34 \%$ ) and severe LBP (score 41\%-60\%; $n=45 ; 18 \%$; Table 1). A significant increase $(P=0.01)$ in BMI, waist circumference, and waistto-hip ratio was reported in schoolchildren with higher LBP disability scores as shown in groups of moderate and severe LBP compared to those with a lower LBP score (Table 1).

Compared to schoolchildren with minimal or no LBP, the duration of sun exposure and the exposed skin areas outdoors were shown to be significantly $(P=0.01)$ lower in schoolchildren with moderate to severe LBP. In moderate and severe LBP groups, $64.7 \%$ and $89 \%$ of the schoolchildren usually wore black clothes outdoors, whereas only $35.3 \%$ and $11.1 \%$ of the schoolchildren usually wore other colors. Approximately $70.6 \%$ and $66.7 \%$ of these clothes were of synthetic fabrics (Table 1).

Regarding to dietary habits, in moderate and severe LBP groups, respectively, only $23.5 \%$ and $22.3 \%$ of the schoolchildren had adequate vitamin $\mathrm{D}$ amounts in their foods and the rest of the schoolchildren (76.5\% and 77.7\%) had lower vitamin $\mathrm{D}$ content in their usual diet (Table 1).

A significant decrease in the serum levels of vitamin $25(\mathrm{OH}) \mathrm{D}$ and $\mathrm{Ca}$ and an increase in the level of sBAP were 
observed in all schoolchildren with moderate $(P=001)$ and severe $(P=0.001)$ LBP scores compared to those with no or minimal LBP scores (Table 2). However, in schoolchildren with moderate to severe LBP scores, a significant increase in the levels of muscle fatigue markers (CK and LDH) was observed. The data obtained were supported by an increase in the muscle fatigue and LBP disability status of the schoolchildren in moderate $(P=0.01)$ and severe LBP $(P=0.001)$ groups as measured by OWS and pain rating scores (Tables 1 and 2), respectively.

Regarding the prevalence of LBP and related risk factors, the relation between LBP scores and gender, BMI, PA, sedentary activities, body weight carried, and average carrying loads was reported in all schoolchildren of this study. The prevalence rate of LBP in the study population was recorded as $\sim 52 \%$ of the total population. At an average age of 14.6-15.1 years, girls showed higher LBP prevalence rates than boys did $(36 \% \mathrm{v} 24 \%, P<0.001)$. In comparison with nonobese $\left(\mathrm{BMI} \leq 25 \mathrm{~kg} / \mathrm{m}^{2}\right)$ schoolchildren higher prevalence rates of LBP $(72 \%)$ were significantly $(P=0.001)$ reported in obese $\left(B M I \geq 25 \mathrm{~kg} / \mathrm{m}^{2}\right)$ schoolchildren of both moderate and severe LBP groups (Table 3 ). In addition, in the same manner, 5-day average load and body weight carried by schoolchildren were shown to be significantly $(P=0.05)$ correlated with LBP prevalence rates. Schoolchildren who carried loads $\geq 5.7 \mathrm{~kg}$ and had body weight $\geq 6.6 \%$ showed prevalence rates of $41 \%$ and $48 \%$ compared to those who carried loads $\leq 5.7 \mathrm{~kg}$ and had body weight $\leq 6.6 \%$, respectively (Table 3 ).

Schoolchildren who participated in moderate to active PA and used active school transport (foot or bike) showed significantly $(P=0.01)$ lower rates of LBP prevalence $(32 \%, 26 \%$, and $31 \%$ ), respectively. However, schoolchildren who participated in mild PAs and used passive school transport (car, bus, and motorbike) showed higher rates of LBP (46\% and $56 \%$ ), respectively (Table 3 ). In addition, sedentary activities were shown to have a significant correlation $(P=0.01)$ with LBP prevalence rates; schoolchildren who used computer and watched TV for $\geq 240$ min showed higher rates of LBP

Table I General characteristics of the schoolchildren according to LBP disability scores (OSW scores; N=250)

\begin{tabular}{|c|c|c|c|}
\hline Parameters & $\begin{array}{l}\text { No or minimal LBP } \\
(0 \%-20 \%)\end{array}$ & $\begin{array}{l}\text { Moderate LBP } \\
(20 \%-40 \%)\end{array}$ & $\begin{array}{l}\text { Severe LBP } \\
(41 \%-60 \%)\end{array}$ \\
\hline Schoolchildren, n (\%) & $120(48)$ & $85(34)$ & $45(18)$ \\
\hline Boys/girls & $55 / 65$ & $33 / 52$ & $13 / 32$ \\
\hline Age (years) & $14.8 \pm 1.52$ & $14.6 \pm 2.3$ & $\mid 5.1 \pm 0.96$ \\
\hline BMI $\left(\mathrm{kg} / \mathrm{m}^{2}\right)$ & $21.2 \pm 1.3$ & $26.4 \pm 2.6 * *$ & $31.9 \pm 4.95^{* *}$ \\
\hline Waist $(\mathrm{cm})$ & $78.9 \pm 3.5$ & $105.6 \pm 12.7 * *$ & $133.7 \pm 9.8^{* *}$ \\
\hline Hips (cm) & $81.2 \pm 2.7$ & $86.4 \pm 8.4 * *$ & $89.3 \pm 5.7 * *$ \\
\hline WHR & $0.46 \pm 0.12$ & $0.58 \pm 0.23 * *$ & $0.65 \pm 0.18^{* *}$ \\
\hline OSW score $(0-100)$ & $9.8 \pm 5.4$ & $28.9 \pm 15.5^{* *}$ & $56.8 \pm 16.4^{* *}$ \\
\hline Pain rating $(0-10)$ & $2.5 \pm 1.3$ & $6.7 \pm 3.9 * *$ & $8.4 \pm 5.9 * *$ \\
\hline Sun exposure duration ( $\mathrm{h} /$ day) & $4.9 \pm 1.7$ & $3.1 \pm 1.5 * *$ & $1.9 \pm 2.4 * *$ \\
\hline Areas of skin exposed (\% of body) & $22.8 \pm 5.4$ & $13.5 \pm 2.9 * *$ & $11.2 \pm 3.5^{* *}$ \\
\hline Color of clothes (black/other), $\mathrm{n}(\%)$ & $25(21) / 95(79.2)$ & $55(64.7) / 30(35.3)$ & $40(89) / 5(11.1)$ \\
\hline Material of clothes (natural/synthetic), n (\%) & $85(71) / 35(29)$ & $25(29.4) / 60(70.6)$ & $15(33.3) / 30(66.7)$ \\
\hline Dietary vitamin D status (low/adequate), $\mathrm{n}(\%)$ & $20(16.7) / 100(83.3)$ & $65(76.5) / 20(23.5)$ & $35(77.7) / 10(22.3)$ \\
\hline
\end{tabular}

Notes: Values are expressed as $n(\%), n / n$, or mean $\pm S D$. $* * P<0.01$. Significance is at $P<0.05$.

Abbreviations: LBP, low back pain; OSW, Oswestry Low Back Pain Disability Questionnaire; BMI, body mass index; WHR, waist-to-hip ratio; SD, standard deviation.

Table 2 Changes in muscle fatigue biomarkers, vitamin $25(\mathrm{OH}) \mathrm{D}$, serum $\mathrm{Ca}$, and sBAP of Schoolchildren based on the levels of LBP disability

\begin{tabular}{llll}
\hline Parameters & $\begin{array}{l}\text { No or minimal LBP } \\
\mathbf{( 0 \% - 2 0 \% ; ~} \mathbf{n}=\mathbf{I 2 0})\end{array}$ & $\begin{array}{l}\text { Moderate LBP } \\
\mathbf{( 2 0 \% - 4 0 \% ; ~} \mathbf{8 5 5 )}\end{array}$ & $\begin{array}{l}\text { Severe LBP } \\
\mathbf{( 4 1 \% - 6 0 \% ; ~} \mathbf{n = 4 5 )}\end{array}$ \\
\hline Vitamin 25(OH)D (nglmL) & $38.6 \pm 10.6$ & $18.8 \pm 7.3 * *$ & $9.5 \pm 4.7 * * * *$ \\
CK (IU/L) & $215.5 \pm 6.4$ & $265 \pm 2.9 * *$ & $327 \pm 7.1 * * *$ \\
LDH (IU/L) & $25.7 \pm 6.3$ & $48.7 \pm 5.4 * *$ & $75.8 \pm 8.9 * * *$ \\
Ca (mg/dL) & $9.8 \pm 1.4$ & $8.1 \pm 0.85 * *$ & $6.9 \pm 0.95 * * *$ \\
sBAP (IU/L) & $21.8 \pm 6.3$ & $29.6 \pm 10.5 * *$ & $33.7 \pm 19.5 * * *$ \\
\hline
\end{tabular}

Notes: $N=250$; OSW score range is $0-100$; values are expressed as mean \pm SD. $* P<0.05$, $* * P<0.01$, and $* * * P<0.001$. Significance is at $P<0.05$.

Abbreviations: Ca, calcium; sBAP, serum bone-specific alkaline phosphatase; LBP, low back pain; OSW, Oswestry Low Back Pain Disability Questionnaire; SD, standard deviation; $\mathrm{CK}$, creatine kinase; LDH, lactate dehydrogenase. 
Table 3 Risk of LBP in relation to mechanical factors, gender, PAs, and sedentary activities among schoolchildren

\begin{tabular}{|c|c|c|c|c|}
\hline Parameters & $\mathbf{n}$ & $\begin{array}{l}\text { LBP } \\
\text { prevalence (\%) }\end{array}$ & OR $(95 \% \mathrm{CI})$ & $P$-value \\
\hline Gender & & & & 0.001 \\
\hline Boys & 101 & 24 & I.2(0.98-I.5) & \\
\hline Girls & 149 & 36 & $1.5(0.8-1.8)$ & \\
\hline BMI $\left(\mathrm{kg} / \mathrm{m}^{2}\right)$ & & & & 0.001 \\
\hline Nonobese $(\leq 25)$ & 120 & 39 & $0.78(0.75-1.32)$ & \\
\hline Obese $(\geq 25)$ & 130 & 72 & $1.28(0.86-1.48)$ & \\
\hline \multicolumn{3}{|c|}{ Average (5-day) load (kg) } & & 0.05 \\
\hline$\leq 5.7$ & 132 & 29 & $0.45(0.35-1.4)$ & \\
\hline$\geq 5.7$ & 118 & 41 & $1.4(0.86-1.6)$ & \\
\hline \multicolumn{3}{|c|}{ Body weight carried (\%) } & & 0.05 \\
\hline$\leq 6.6$ & 124 & 35 & $0.72(0.66-1.7)$ & \\
\hline$\geq 6.6$ & 136 & 48 & I.I (0.86-I.32) & \\
\hline \multicolumn{5}{|c|}{ School transport used } \\
\hline $\begin{array}{l}\text { Active (on foot } \\
\text { or bike) }\end{array}$ & 120 & 31 & $1.25(0.86-1.7)$ & 0.01 \\
\hline $\begin{array}{l}\text { Passive (car, } \\
\text { bus, motorbike) }\end{array}$ & 130 & 56 & $1.3(0.78-1.36)$ & \\
\hline \multicolumn{5}{|l|}{ PA (min/week) } \\
\hline Mild $(\leq 165)$ & 125 & 46 & I.I (0.96-I.4) & 0.001 \\
\hline $\begin{array}{l}\text { Moderate } \\
(165-280)\end{array}$ & 45 & 32 & $1.6(0.98-1.95)$ & \\
\hline Active $(\geq 280)$ & 80 & 26 & $1.2(0.68-1.42)$ & \\
\hline \multicolumn{5}{|c|}{ Sedentary activities (min/day) } \\
\hline$\leq 240$ & 160 & 28 & $1.3(0.88-1.45)$ & 0.01 \\
\hline$\geq 240$ & 90 & 46 & $1.0(0.75-1.2)$ & \\
\hline
\end{tabular}

Notes: $\mathrm{N}=250$; data shown as mean $\pm \mathrm{SD}$; $P$-value $<0.05$. ORs adjusted for age and gender in a logistic regression model.

Abbreviations: LBP, low back pain; PA, physical activity; SD, standard deviation; $\mathrm{OR}$, odds ratio; $\mathrm{Cl}$, confidence interval; $\mathrm{BMI}$, body mass index. compared with those who watched TV and used computer for $\leq 240 \min$ (Table 3).

Based on vitamin 25(OH)D status, schoolchildren were classified into three groups: normal ( $\geq 30 ; n=100 ; 40 \%)$, insufficient (21-29; $\mathrm{n}=90 ; 36 \%)$, and deficient $(\leq 20 ; \mathrm{n}=60$; $24 \%$ ). Vitamin D status was negatively and significantly associated with LBP disability scores, BMI, pain rating score, $\mathrm{CK}, \mathrm{LDH}$, usually wearing black clothes, and clothes made of synthetic fabrics and positively associated with PA, longer sun exposure, areas of skin exposed, serum $\mathrm{Ca}$, and sBAP in all groups. This correlation suggested the importance of vitamin $25(\mathrm{OH}) \mathrm{D}$ levels toward obesity, muscle fatigue, and the occurrence of LBP in physically inactive and physically active schoolchildren, which is shown in Table 4.

Stepwise regression analysis revealed that age, gender, demographic parameters, $\mathrm{PA}$, vitamin D levels, $\mathrm{Ca}, \mathrm{CK}$, and LDH associated with $\sim 56.8 \%-86.7 \%$ of the incidence of LBP among schoolchildren aged 12-16 years (Table 5).

\section{Discussion}

For many years, LBP in children and adolescents was considered as a sign of serious disease. ${ }^{59,60}$ Higher prevalence rates of nonspecific LBP were epidemiologically reported in children than adults as a result of some biological risk factors that increase in rates during adulthood. ${ }^{61,62}$ However, there was difficulty in comparing epidemiological measurements, ${ }^{62}$ this may be related to methodological differences, including

Table 4 Correlation matrix between LBP disability score, adiposity, and muscle fatigue-related biomarkers in schoolchildren ( $\mathrm{n}=250$ ) based on vitamin $25(\mathrm{OH}) \mathrm{D}$ status

\begin{tabular}{|c|c|c|c|}
\hline \multirow[t]{2}{*}{ Variables } & \multicolumn{3}{|c|}{ Vitamin 25(OH)D status (ng/mL), $R$} \\
\hline & $\begin{array}{l}\text { Normal }(\geq 30 \text {, } \\
n=100 ; 40 \%)\end{array}$ & $\begin{array}{l}\text { Insufficient (2I-29, } \\
n=90 ; 36 \%)\end{array}$ & $\begin{array}{l}\text { Deficient ( } \leq 20 \text {, } \\
n=60 ; 24 \%)\end{array}$ \\
\hline \multicolumn{4}{|l|}{ LBP } \\
\hline Minimal (0\%-20\%) & $-0.58^{* *}$ & $-0.49 * *$ & $-0.6 I * *$ \\
\hline Moderate LBP (20\%-40\%) & $-0.26 * *$ & $-0.35^{* *}$ & $-0.28 * *$ \\
\hline Severe LBP (4I\%-60\%) & $-0.35 * *$ & $-0.25 * *$ & $-0.2 I^{* *}$ \\
\hline Pain rating score & $-0.28 * *$ & $-0.18 * *$ & $-0.31 * *$ \\
\hline \multicolumn{4}{|l|}{$\mathrm{BMI}\left(\mathrm{kg} / \mathrm{m}^{2}\right)$} \\
\hline Nonobese $(\leq 25)$ & $-0.85 * *$ & $-0.55 * *$ & $-0.75^{* *}$ \\
\hline Obese $(\geq 25)$ & $-0.95 * *$ & $-0.79 * *$ & $-0.92 * *$ \\
\hline CK (IU/L) & $-0.52^{*}$ & $-0.64^{*}$ & $-0.48^{*}$ \\
\hline LDH (IU/L) & $-0.45^{*}$ & $-0.26^{*}$ & $-0.38^{*}$ \\
\hline $\mathrm{Ca}(\mathrm{mg} / \mathrm{dL})$ & $0.32 *$ & $0.24 *$ & $0.45^{*}$ \\
\hline sBAP (IU/L) & $0.65 * *$ & $0.18 * *$ & $0.35^{* *}$ \\
\hline PA & $0.68 * *$ & $0.34 * *$ & $0.5 \mathrm{I} * *$ \\
\hline Sun exposure duration (h/day) & $0.85 * *$ & $0.75 * *$ & $0.69 * *$ \\
\hline Areas of skin exposed (\% of body) & $0.51 * *$ & $0.59 * *$ & $0.68 * *$ \\
\hline Color of clothes (black/other) & $-0.46^{*}$ & $-0.58^{*}$ & $-0.38 *$ \\
\hline Material of clothes (natural/synthetic) & $-0.29 * *$ & $-0.36 * *$ & $-0.39 * *$ \\
\hline Vitamin D diet & $0.43 * *$ & $0.47 * *$ & $0.51 * *$ \\
\hline
\end{tabular}

Notes: Data are presented as coefficient $(R)$. *Significance at $P<0.05 ; * *$ significance at $P<0.01$.

Abbreviations: LBP, low back pain; OSW, Oswestry Low Back Pain Disability Questionnaire; BMI, body mass index; CK, creatine kinase; LDH, lactate dehydrogenase; Ca, calcium; sBAP, serum bone-specific alkaline phosphatase; PA, physical activity. 
Table 5 Beta coefficients and cumulative $R^{2}$ values derived from stepwise multiple regression models

\begin{tabular}{|c|c|c|c|c|c|c|}
\hline \multirow[t]{3}{*}{ Variables } & \multicolumn{6}{|c|}{ LBP disability status (OSW score, 0-100) } \\
\hline & \multicolumn{2}{|c|}{ Minimal (0\%-20\%) } & \multicolumn{2}{|c|}{ Moderate (21\%-40\%) } & \multicolumn{2}{|c|}{ Severe $(41 \%-60 \%)$} \\
\hline & $R^{2}(\beta)^{*}$ & $95 \% \mathrm{Cl}$ & $R^{2}(\beta) * *$ & $95 \% \mathrm{Cl}$ & $R^{2}(\beta) * *$ & $95 \% \mathrm{Cl}$ \\
\hline Age & $9.5(0.58)$ & $75(65-87)$ & $8.1(0.38)$ & $91(65-98)$ & $6.5(0.47)$ & $87(65-100)$ \\
\hline Gender & $4.1(0.25)$ & $95(65-100)$ & $3.4(0.34)$ & $96(7 \mid-100)$ & $3.8(0.54)$ & $86(75-100)$ \\
\hline Body weight (kg) & $15.4(0.48)$ & $85(75-100)$ & $\mathrm{II} .4(0.2 \mathrm{I})$ & $84(75-98)$ & $10.4(0.28)$ & $81(75-98)$ \\
\hline BMI $\left(\mathrm{kg} / \mathrm{m}^{2}\right)$ & $8.9(0.35)$ & $95(56-100)$ & $5.3(0.25)$ & $89(74-100)$ & $5.1(0.46)$ & 91 (74-98) \\
\hline Vitamin $25(\mathrm{OH}) \mathrm{D}$ & $26.4(0.3 \mathrm{I})$ & $72(65-96)$ & $16.5(0.56)$ & $86(68-96)$ & II.5 (0.49) & $78(68-98)$ \\
\hline \multicolumn{7}{|l|}{ status $(\mathrm{ng} / \mathrm{mL})$} \\
\hline CK (IU/L) & $1.8(0.13)$ & $78(65-100)$ & $3.1(0.24)$ & $76(65-100)$ & $4.7(0.34)$ & $69(65-96)$ \\
\hline LDH (IU/L) & $3.1(0.31)$ & 87 (69-98) & $2.6(0.42)$ & 90 (69-98) & $4.5(0.47)$ & $95(69-100)$ \\
\hline $\mathrm{Ca}(\mathrm{mg} / \mathrm{dL})$ & $8.6(0.47)$ & 59 (42-89) & $5.6(0.37)$ & 68 (56-95) & $4.6(0.48)$ & 85 (76-98) \\
\hline sBAP (IU/L) & $3.5(0.28)$ & 81 (65-96) & $1.9(0.34)$ & 92 (78-98) & $2.3(0.54)$ & 91 (78-98) \\
\hline PA (min/week) & $5.7(0.29)$ & $59(4 \mid-86)$ & $3.7(039)$ & $95(86-100)$ & $3.4(0.28)$ & $89(86-100)$ \\
\hline$\Sigma R^{2}(\%)$ & $86.7(0.34)$ & $98(75-100)$ & $61.5(0.35)$ & $91(85-100)$ & $56.8(0.34)$ & $95(85-100)$ \\
\hline
\end{tabular}

Note: $* P<0.05 ; * P<0.01 . \Sigma R^{2}=$ summation of cumulative values of $R$ relating to studied variables.

Abbreviations: LBP, low back pain; OSW, Oswestry Low Back Pain Disability Questionnaire; Cl, confidence interval; BMI, body mass index; CK, creatine kinase; LDH, lactate dehydrogenase; $\mathrm{Ca}$, calcium; sBAP, serum bone-specific alkaline phosphatase; PA, physical activity.

LBP definitions and age of the schoolchildren studied. Thus, the prevalence rates of back pain recorded significant variation from one study $(20 \%-51 \%)^{63}$ to another study $(35 \%)$, which was performed on secondary school schoolchildren. ${ }^{64}$ In addition, little is known about both biochemical and physiological consequences related to LBP among children and adolescents. Hence, the effects of vitamin D deficiency, muscle performance, and mechanical factors, including physical and sedentary activities, on LBP prevalence rates among schoolchildren were our concern in this study.

In the present study, LBP was reported in $52 \%$ of the study schoolchildren as measured by the presence of higher scores of Pain Rating Scale and a modified OSW. LBP was categorized into moderate (34\%) and severe (18\%); 48\% of the schoolchildren had lower OSW scores, and they were diagnosed as having no or minimal LBP.

Previous research studies reported that LBP was frequent among schoolchildren and increases with age, ${ }^{65-67}$ and LBP was estimated in $11 \%-71 \%$ of the schoolchildren by the age of 14-17 years. ${ }^{68}$ In addition, in previous survey studies, LBP was reported in a range of $11 \%-80 \%$ of the total population aged $<20$ years, which is lower than that in our study schoolchildren. ${ }^{69,70}$ In the literature, it was reported that during lifetime, the cumulative LBP prevalence rates varied from $21 \%$ to $74 \% .{ }^{71}$ In addition, in our study, LBP was estimated in one school year season, which may be $>10$ months; hence, our results may be in line with Burton et al who reported an increment in LBP rates from $11.8 \%$ to $21.5 \%$ in adolescents aged $11-15$ years and a similar increase in lifetime prevalence rates of LBP from $11.6 \%$ to $50.4 \%$ at the same age period. In addition, LBP prevalence was shown to increase linearly by age from 4 to 65 years, ${ }^{72}$ and children showed LBP prevalence rates ranging from $7 \%$ to $58 \%$. $^{73,74}$

Previous studies showed that the prevalence of LBP among children, adolescents, and young adults may be related to unknown etiological factors. ${ }^{6,69,73,74}$ Thus, in this study, the relation between a series of mechanical factors related to activity and sedentary lifestyle and the occurrence of LBP was estimated in a group of schoolchildren.

There was a significant correlation between LBP prevalence rates and BMI, 5-day average load of school bags, and body weight carried by schoolchildren. Higher prevalence rates of LBP $(72 \%)$ were reported in obese schoolchildren $\left(\mathrm{BMI} \geq 25 \mathrm{~kg} / \mathrm{m}^{2}\right)$ of both genders; however, girls showed higher LBP prevalence rates than boys ( $36 \%$ vs $24 \%$, $P<0.001)$. In addition, schoolchildren who carried loads such as school bags of $\geq 5.7 \mathrm{~kg}$ and exceeded body weight by $\geq 6.6 \%$ showed higher ranges of LBP $(41 \%-48 \%)$. Like our study, the associations of BMI with LBP have been reported previously. ${ }^{75}$

In addition, our data were in accordance with those who reported higher rates of LBP among girls than those among boys. ${ }^{76}$ Musculoskeletal pain was more likely to prevail among adolescents with more heterogeneity, and both overweight and obesity syndromes similarly increased the risk of LBP. ${ }^{77-79}$

Despite the lack of confirmational evidence data, BMI and body height were shown to be associated with the pathogenesis of LBP. Excessive load-bearing resulting from obesity would require more mechanical demands that are suspected to participate in the occurrence of LBP, and the change in metabolic factors related to obesity such as adipose tissues, 
which release many inflammatory cytokines, may have a role in the pathogenesis of LBP. ${ }^{80,81}$ Recently, it was suggested that obesity may be responsible for the continuous growth of LBP among young adults. ${ }^{82}$ In addition, in our study, both school bag overloads and body weight carried by schoolchildren, which exceeded to $10 \%$ of the relative body weight, were considered as higher risk factors for LBP as mentioned before. ${ }^{83,84}$ However, in another study, little evidence was reported on the association of mechanical loads across the range of weights carried by children to school with the prevalence of $\mathrm{LBP}^{85}$

Regarding PA, schoolchildren who participated in active sports programs, walked to school, or used active school transport such as bike showed lower ranges of LBP prevalence (26\%-32\%). However, schoolchildren who participated in mild daily activities and used passive school transport, such as car, bus, and motorbike, showed higher ranges of LBP $(46 \%-56 \%)$. The data of our study were in line with other studies that reported an association between lower PA and the incidence of LBP ${ }^{83,84}$ In addition, in some previous studies, physical inactivity, inactive school transport, and intensive sports were shown to be associated with the prevalence of LBP among children and adolescents. ${ }^{86-91}$

In addition, sedentary activities of the schoolchildren showed a significant correlation $(P=0.01)$ with LBP prevalence rates. Schoolchildren who used computer and watched TV for $\geq 240$ min showed higher rates of LBP (46\%) compared with those who watched TV and used computer for $\leq 240 \mathrm{~min}$. The data of our study were in accordance with previous cross-sectional studies that reported a significant association between LBP and time spent watching television ${ }^{92}$ and playing video games $;{ }^{93}$ however, this association was not found in other studies. ${ }^{94}$

Vitamin D was shown to play an essential role in the mineralization of normal bone via maintaining adequate amounts of $\mathrm{Ca}$ and $\mathrm{P}^{95-97}$ It was supplied either from adequate healthy diets or produced as a precursor in human skin following exposure to sufficient ultraviolet light. ${ }^{97}$

In this study, $\sim 40 \%$ of the study population had a normal range of vitamin $25(\mathrm{OH}) \mathrm{D}$ levels $(\geq 30 \mathrm{ng} / \mathrm{mL}$ ) without $\mathrm{LBP}$, and $60 \%$ of the population had lower levels of serum vitamin $25(\mathrm{OH}) \mathrm{D}$; they were classified on the basis of insufficient vitamin D (21-29 ng/mL; 36\%) and deficient vitamin D ( $\leq 20 \mathrm{ng} /$ $\mathrm{mL} ; 24 \%$ ) as those with moderate and severe LBP, respectively. A significant decrease in the serum levels of vitamin $25(\mathrm{OH}) \mathrm{D}$ and $\mathrm{Ca}$, and an increase in the level of sBAP were reported in all schoolchildren with moderate $(P=001)$ and severe $(P=0.001)$ LBP scores compared to schoolchildren with no or minimal LBP scores and normal serum vitamin D levels.
It was reported previously that sufficient serum levels of vitamin $\mathrm{D}, \mathrm{Ca}$, and $\mathrm{P}$ are required for better bone health and muscle performance. ${ }^{24-26}$ Many studies also reported a high prevalence of vitamin $\mathrm{D}$ deficiency in various populations with nonspecific musculoskeletal pain, including LBP. ${ }^{27-29}$ Recently, vitamin D deficiency was proposed as a potential causative factor in the pathogenesis and conservation of pain conditions, including chronic LBP. ${ }^{98-100}$ A higher prevalence rate of vitamin $\mathrm{D}$ deficiency was reported among populations with musculoskeletal and/or widespread pain conditions. Some studies showed high prevalences of suboptimal vitamin D levels in populations with musculoskeletal and/ or widespread pain conditions. ${ }^{98-101}$

The most important parameters affecting the level of vitamin $25(\mathrm{OH}) \mathrm{D}$ in this study were vitamin $\mathrm{D}$ in diet, sunlight exposure, and wearing black clothes or clothes made of synthetic fibers.

Wearing black clothes or clothes made of synthetic fibers was significantly associated with lower vitamin $25(\mathrm{OH}) \mathrm{D}$ levels in schoolchildren with moderate and severe LBP. The data were in agreement with those who reported a significant association between age, lifestyle, clothing, and the development of hypovitaminosis D. The logical reason is that clothes made of black wool prevent most of the incident UV rays $(98.6 \%)$ compared with little amount of white cotton (47.7\%). ${ }^{102,103}$

In this study, diets with a lower vitamin $\mathrm{D}$ content were significantly associated with a lower level of vitamin $25(\mathrm{OH})$ $\mathrm{D}$ in schoolchildren with both moderate and severe LBP. Our data supported that diet may correlate significantly with vitamin D levels as shown previously in literature. ${ }^{104-106}$

Adequate exposure to sunshine played the most pivotal role in affecting vitamin D status in our schoolchildren. The duration of sunlight exposure reported $52 \%$ of the variation in serum levels of vitamin D in schoolchildren with moderate and severe LBP, whereas the percentage of areas exposed separately reported an extra variance in vitamin D status with $11.2 \%-13.5 \%$. Thus, the data of our study clearly support the importance of longer time of sunlight exposure rather than skin areas exposed on vitamin D status. Our data were in agreement with previous research, which reported that both dark skin and less pigmented skin need three to six times more sun light exposure to produce a similar ratio of vitamin D. ${ }^{26}$ In addition, other studies confirm our results that both longer duration of sunlight exposure and skin left exposed by different dressing styles were significantly associated with vitamin D levels. ${ }^{107-110}$

Regarding the role of muscle fatigue in the progression of LBP among schoolchildren, muscle fatigue markers, $\mathrm{CK}$ and $\mathrm{LDH}$, and pain rating scores were estimated in all 
schoolchildren. Schoolchildren with moderate and severe LBP showed a significant $(P=0.001)$ increase in the serum levels of $\mathrm{CK}$ and $\mathrm{LDH}$ along with higher pain rating scores compared to those with no or minimal LBP.

Vitamin D is essential for the development and maintenance of musculoskeletal system for the best function of the muscles and nervous system throughout the life of a human body. ${ }^{24}$ The reduction in muscle performance, which leads to LBP, was shown to be associated with vitamin D deficiency and physical inability in adolescents, especially girls. Whereas muscle power and force are linked with vitamin D levels, ${ }^{37}$ these may produce a significant myopathy that leads to muscle fatigue and reduced motivation to daily activities. $^{30,34}$ The severity of LBP in our study population may be related to physiological change in the behavior of musculoskeletal system as a result of change in normal levels of $\mathrm{Ca}, \mathrm{CK}$, and $\mathrm{LDH}$, whereas muscle membrane, contraction, and energy metabolism depend on ionic regulation of certain minerals and enzymes. The irregularity in the levels of muscle lactate, hydrogen $\left(\mathrm{H}^{+}\right)$, and calcium $\left(\mathrm{Ca}^{2+}\right)$ ions was shown to be linked with muscle fatigue. ${ }^{11,112}$ In addition, the release of intramuscular enzymes, such as CK and LDH, may be related to collagen fiber degradation either by overuse or strained muscle damage. ${ }^{113-115}$

In relation to vitamin $\mathrm{D}$ status, the deficiency in the levels of vitamin $25(\mathrm{OH}) \mathrm{D}$ reported in schoolchildren with moderate and severe LBP correlated negatively with LBP disability scores, BMI, pain rating score, $\mathrm{CK}$, $\mathrm{LDH}$, and wearing black clothes made of synthetic fabrics and positively with PA, longer sun exposure, areas of skin exposed, serum $\mathrm{Ca}$, and sBAP in all groups. This correlation was confirmed with previous studies that reported that the deficiency in vitamin D may be related to poor PA, ${ }^{30}$ adiposity, minimal sun exposure, ${ }^{31-33}$ and insufficient dietary intake or impairments in metabolic activation of the vitamin. ${ }^{34-37}$ In addition, vitamin $25(\mathrm{OH})$ $\mathrm{D}$ deficiency was significantly reported in healthy growing children and adolescents in many countries, ${ }^{46-116}$ and it was significantly correlated with higher levels of serum sBAP, which may contribute to both optimizing bone mass and muscle strength. ${ }^{117}$

Finally, stepwise regression analysis performed in this study revealed that age, gender, demographic parameters, PA, vitamin D levels, Ca, CK, and $\mathrm{LDH}$ associated with $\sim 56.8 \%-86.7 \%$ of the incidence of LBP among schoolchildren aged $12-16$ years.

\section{Limitation}

Our study is cross-sectional in nature and could only estimate features such as anthropometry, lifestyle factors, mechanical load, and PA associated with LBP, rather than risk factors (or markers) associated with its development, which needs more clinical-based studies. In addition, in this study, it is not yet available to estimate whether LBP and vitamin D deficiency are actually directly related. The presence of vitamin $\mathrm{D}$ deficiency in association with LBP may be related to consequences of sedentary lifestyle, mechanical factors, and less sun exposure. Hence, the mechanistic roles of vitamin D, Ca, CK, and LDH to predispose LBP in children and adolescents will be investigated in the next phase of our longitudinal population study.

\section{Conclusion}

The data obtained concluded that vitamin 25(OH)D deficiencies were significantly associated with the occurrence of LBP among children and adolescents aged 12-16 years, which may have contributed to the significant change in the levels of $\mathrm{Ca}, \mathrm{CK}$, and LDH; limited sun exposure; inadequate vitamin D diets; adiposity; lower PA; and sedentary lifestyles. However, it is not available to estimate whether LBP and vitamin D deficiency are actually directly related. In addition, the data concluded that adequate healthy diets, longer sun exposure, and good PA could be used as good preventive strategies against the occurrence of LBP among schoolchildren.

\section{Acknowledgment}

The authors are grateful to the Deanship of Scientific Research, King Saud University, for funding through Vice Deanship of Scientific Research Chairs.

\section{Disclosure}

The authors report no conflicts of interest in this work.

\section{References}

1. Kordi R, Rostami M. Low back pain in children and adolescents: an algorithmic clinical approach. Iran J Pediatr. 2011;21(3):259-270.

2. Burton AK, Clarke RD, McClune TD, Tillotson KM. The natural history of low back pain in adolescents. Spine. 1996;21(20):2323-2328.

3. Leboeuf-Yde C, Kyvik KO. At what age does low back pain become a common problem? A study of 29,424 individuals aged $12-41$ years. Spine. 1998;23(2):228-234.

4. Harreby M, Nygaard B, Jessen T, et al. Risk factors for low back pain in a cohort of 1389 Danish school children: an epidemiologic study. Eur Spine J. 1999;8(6):444-450.

5. Taimela S, Kujala UM, Salminen JJ, Viljanen T. The prevalence of low back pain among children and adolescents. A nationwide, cohort-based questionnaire survey in Finland. Spine. 1997;22(10):1132-1136.

6. Calvo-Muñoz I, Gómez-Conesa A, Sánchez-Meca J. Prevalence of low back pain in children and adolescents: a meta-analysis. BMC Pediatr. 2013;13:14.

7. Sjolie AN. Low-back pain in adolescents is associated with poor hip mobility and high body mass index. Scand JMed Sci Sports. 2004;14(3): $168-175$.

8. Cakmak A, Yücel B, Ozyalçn SN, et al. The frequency and associated factors of low back pain among a younger population in Turkey. Spine. 2004;29(14):1567-1572. 
9. Gunzburg R, Balagué F, Nordin M, et al. Low back pain in a population of school children. Eur Spine J. 1999;8(6):439-443.

10. Feldman DE, Shrier I, Rossignol M, Abenhaim L. Risk factors for the development of low back pain in adolescence. Am J Epidemiol. 2001;154(1):30-36.

11. Moncer R, Jemni S, Frioui S, et al. Cross-sectional study of low-back pain (LBP) in children and adolescents: prevalence and risk factor. Ann Phys Rehabil Med. 2016;59S:e96

12. Feldman DE, Rossignol M, Shrier I, Abenhaim L. Smoking. A risk factor for development of low back pain in adolescents. Spine. 1999;24(23):2492-2496.

13. van Gent C, Dols JJ, de Rover CM, Hira Sing RA, de Vet HC. The weight of schoolbags and the occurrence of neck, shoulder, and back pain in young adolescents. Spine (Phila Pa 1976). 2003;28(9):916-921.

14. Widhe T. Spine: posture, mobility and pain. A longitudinal study from childhood to adolescence. Eur Spine J. 2001;10(2):118-123.

15. Harreby M, Kjer J, Hesselsøe G, Neergaard K. Epidemiological aspects and risk factors for low back pain in 38-year-old men and women: a 25 -year prospective cohort study of 640 school children. Eur Spine J. 1996;5(5):312-318.

16. Kujala UM, Taimela S, Salminen JJ, Oksanen A. Baseline anthropometry, flexibility and strength characteristics and future low back pain in adolescent athletes and nonathletes. Scand J Med Sci Sports. 1994;4(3):200-205.

17. Sjölie AN, Ljunggren AE. The significance of high lumbar mobility and low lumbar strength for current and future low back pain in adolescents. Spine. 2001;26(23):2629-2636.

18. Newcomers K, Sinaki M. Low back pain and its relationship to back strength and physical activity in children. Acta Paediatr. 1996;85(12):1433-1439.

19. Fernandes JA, Genebra CV, Maciel NM, Fiorelli A, de Conti MH, De Vitta A. Low back in schoolchildren: A cross-sectional study in a western city of São Paulo State, Brazil. Acta Ortop Bras. 2015;23(5):235-238.

20. Negrini S, Carabalona R, Sibilla P. Backpack as a daily load for schoolchildren. Lancet. 1999;354(9194):1974.

21. Troussier B, Davoine P, de Gaudemaris R, Fauconnier J, Phelip X. Back pain in school children: a study among 1178 pupils. Scand $J$ Rehabil Med. 1994;26(3):143-146.

22. Grimmer K, Williams M. Gender-age environmental associates of adolescent low back pain. Appl Ergon. 2000;31(4):343-360.

23. Viry P, Creveuil C, Marcelli C. Nonspecific back pain in children. A search for associated factors in 14 year old schoolchildren. Rev Rhum Engl Ed. 1999;66(7-9):381-388.

24. Leavitt SB. Vitamin D-A Neglected Analgesic for Chronic Musculoskeletal Pain. Pain Treatment Topics 2008. Available from: http:// pain-topics.org/pdf/vitamind-report.pdf. Accessed February 7, 2013.

25. Sheikh A, Saeed Z, Jafri SAD, Yazdani I, Hussain SA. Vitamin D levels in asymptomatic adults-a population survey in Karachi, Pakistan. PLoS One. 2012;7(3):e33452.

26. Donath SM, Amir LH. Breastfeeding and the introduction of solids in Australian infants: data from the 2001 National Health Survey. Aust N Z J Public Health. 2005;29(2):171-175.

27. Plotnikoff GA, Quigley JM. Prevalence of severe hypovitaminosis D in patients with persistent, nonspecific musculoskeletal pain. Mayo Clin Proc. 2003;78(12):1463-1470.

28. Mattam A, Sunny G. Correlation of vitamin $d$ and body mass index with modic changes in patients with non-specific low back pain in a sub-tropical asian population. Asian Spine J. 2016;10(1):14-19.

29. Plehwe WE, Carey RPL. Spinal surgery and severe vitamin D deficiency. Med J Austr. 2002;176(9):438-439.

30. Kennel KA, Drake MT, Hurley DL. Vitamin D deficiency in adults: when to test and how to treat. Mayo Clin Proc. 2010;85(8):752-757.

31. Elsammak MY, Al-Wosaibi AA, Al-Howeish A, Alsaeed J. Vitamin D deficiency in Saudi Arabs. Horm Metab Res. 2010;42(5):364-368.

32. Hutchinson MS, Grimnes G, Joakimsen RM, Figenschau Y, Jorde R. Low serum 25-hydroxyvitamin D levels are associated with increased all-cause mortality risk in a general population: the Tromsø study. Eur J Endocrinol. 2010;162(5):935-942.
33. SACN (Scientific Advisory Committee on Nutrition). Update on Vita$\min \mathrm{D} ; 2007$. London. Available from: https://www.gov.uk/government/ publications/sacn-update-on-vitamin-d-2007. Accessed February 7, 2013.

34. Pérez-López FR. Vitamin D and its implications for musculoskeletal health in women: an update. Maturitas. 2007;58(2):117-137.

35. Ceglia L. Vitamin D and its role in skeletal muscle. Curr Opin Clin Nutr Metab Care. 2009;12(6):628-633.

36. Faraj S, Mutairi K. Vitamin D deficiency and chronic low back pain in Saudi Arabia. Spine. 2003;28(2):177-179.

37. Samson MM, Meeuwsen IB, Crowe A, Dessens JA, Duursma SA, Verhaar HJ. Relationships between physical performance measures, age, height and body weight in healthy adults. Age Ageing. 2000;29(3):235-242.

38. Metzl J. Back pain in the adolescent. A user friendly guide. Adolesc Health Update. 2005;17:1.

39. Kim H, Green D. Adolescent back pain. Curr Opin Pediatr. 2008; 20(1):3745.

40. Macias B, Murthy G, Chambers H, Hargens A. Asymmetric loads and pain associated with backpack carrying by children. J Pediatr Orthop. 2008;28(5):512517.

41. Rodriguez-Oviedo P, Ruano-Ravina A, Perez-Rios M, et al. School children's backpacks, back pain and back pathologies. Arch Dis Child. 2012;97(8):730732.

42. Biering-Sorensen F. Physical measurements as risk indicators for low-back trouble over a one-year period. Spine. 1984;9(2):106-119.

43. Lombao Iglesias D, Bagó Granell J, Vilor Rivero T. Validity of creatine kinase as an indicator of muscle injury in spine surgery and its relation with postoperative pain. Acta Orthop Belg. 2014;80(4):545-550.

44. Kotil K, Tunckale T, Tatar Z, Koldas M, Kural A, Bilge T. Serum creatine phosphokinase activity and histological changes in the multifidus muscle: a prospective randomized controlled comparative study of discectomy with or without retraction. J Neurosurg Spine. 2007;6(2): 121-1255.

45. Al-Eisa ES, Alghadir AH, Gabr SA. Correlation between vitamin D levels and muscle fatigue risk factors based on physical activity in healthy older adults. Clin Interv Aging. 2016;11:513-522.

46. Jones G, Dwyer T, Hynes KL, Parameswaran V, Greenaway TM. Vitamin D insufficiency in adolescent males in Southern Tasmania: prevalence, determinants, and relationship to bone turnover markers. Osteoporos Int. 2005;16(6):636-641.

47. Foo LH, Zhang Q, Zhu K, et al. Low vitamin D status has an adverse influence on bone mass, bone turnover, and muscle strength in Chinese adolescent girls. J Nutr. 2009;139(5):1002-1007.

48. Fritz JM, Irrgang JJ. A comparison of a modified Oswestry Low Back Pain Disability Questionnaire and the Quebec Back Pain Disability Scale. Phys Ther. 2001;81(2):776-788.

49. Fritz JM, Clifford SN. Low back pain in adolescents: a comparison of clinical outcomes in sports participants and nonparticipants. J Athl Train. 2010;45(1):61-66.

50. Clifford SN, Fritz JM. Children and adolescents with low back pain: a descriptive study of physical examination and outcome measurement. J Orthop Sports Phys Ther. 2003;33(9):513-522.

51. Watson KD, Papageorgiou AC, Jones GT, et al. Low back pain in schoolchildren: the role of mechanical and psychosocial factors. Arch Dis Child. 2003;88(1):12-17.

52. Cole TJ, Bellizzi MC, Flegal KM, Dietz WH. Establishing a standard definition for child overweight and obesity worldwide: international survey. BMJ. 2000;320(7244):1240-1243.

53. Jones GT, Watson KD, Silman AJ, Symmons DP, Macfarlane GJ. Predictors of low back pain in British schoolchildren: a population-based prospective cohort study. Pediatrics. 2003;111(4 pt 1):822-828.

54. Lavigne $\mathrm{V}$. Weight limit recommendation in backpack use for schoolaged children. J Clin Chirop Pediatr. 2014;14(2):1156-1159.

55. Hassannia T, GhaznaviRad E, Vakili R, Taheri S, Rezaee SA. High Prevalence of Vitamin D Deficiency and Associated Risk Factors among Employed Women in a Sunny Industrial City. Int JVitam Nutr Res. 2015; 85(3-4):119-128. 
56. Alghadir AH, Aly FA, Gabr SA. Effect of moderate aerobic training on bone metabolism indices among adult humans. Pak J Med Sci. 2014;30(4):840-844.

57. Mcgrouther DA. Skin burns. In: Mann CV, Russel RCG, Williams NS, editors. Bailey and Love's Short Practice of Surgery. London: Chapman and Hall; 1995:124-148.

58. Lotfi A, Abdel-Nasser AM, Hamdy A, Omran AA, El-Rehany MA. Hypovitaminosis D in female patients with chronic low back pain. Clin Rheumatol. 2007;26(11):1895-1901.

59. Zapata KA, Wang-Price SS, Sucato DJ, et al. Spinal Stabilization Exercise Effectiveness for Low Back Pain in Adolescent Idiopathic Scoliosis: A Randomized Trial. Pediatr Phys Ther. 2015;27(4):396-402.

60. Macedo RB, Coelho-e-Silva MJ, Sousa NF, et al. Quality of life, school backpack weight, and nonspecific low back pain in children and adolescents. J Pediatr (Rio J). 2015;91(3):263-269.

61. Adegoke BO, Odole AC, Adeyinka AA. Adolescent low back pain among secondary school students in Ibadan, Nigeria. Afr Health Sci. 2015;15(2):429-437

62. Chiwaridzo M, Naidoo N. Are parents and adolescents in agreement on reporting of recurrent non-specific low back pain in adolescents? A cross-sectional descriptive study. BMC Pediatr. 2015;8;15:203.

63. Higuchi Y, Izumi H, Kamashiro M. Development of a simple scale to evaluate the severity of nonspecific low back pain for industrial ergonomics. Ergonomics. 2010;53(6):801-811.

64. Gatchel RJ, Rollings KH. Evidence informed management of chronic low back pain with cognitive behavioral therapy. Spine J. 2008;8(1): 40-44.

65. Whittfield J, Legg SJ, Hedderley DI. Schoolbag weight and musculoskeletal symptoms in New Zealand secondary schools. Appl Ergon. 2003; 36(2):199-205.

66. Wedderkopp N, Leboeuf-Yde C, Andersen LB, Froberg K, Hansen HS. Back pain reporting pattern in a Danish population-based sample of children and adolescents. Spine. 2001;26(17):1879-1883.

67. Olsen TL, Anderson RL, Dearwater SR, et al. The epidemiology of low back pain in an adolescent population. Am J Public Health. 1992;82(4):606-608.

68. Balagué F, Nordin M, Skovron ML, Dutoit G, Yee A, Waldburger M. Non-specific low-back pain among schoolchildren: a field survey with analysis of some associated factors. J Spinal Disord. 1994;7(5): 374-379.

69. Johansson MS, Jensen Stochkendahl M, Hartvigsen J, Boyle E, Cassidy JD. Incidence and prognosis of mid-back pain in the general population: A systematic review. Eur J Pain. 2017;21(1):20-28.

70. Deyo RA, Tsui-Wu Y-J. Descriptive epidemiology of low-back pain and its related medical care in the United States. Spine. 1987;12(3):264-268.

71. Jones G, Macfarlane G. Epidemiology of low back pain in children and adolescents. Arch Dis Child. 2005;90(3):312-316.

72. MacDonald J, Stuart E, Rodenberg R. Musculoskeletal low back pain in school-aged children: a review. JAMA Pediatr. 2017;1;171(3):280-287.

73. Smith DR, Leggat PA. Back pain in the young: a review of studies conducted among schoolchildren and university students. Cur Pediatr Rev. 2007;3(1):69-77.

74. Woolf AD, Pfleger B. Burden of major musculoskeletal conditions. Bull World Health Organ. 2003;81(9):646-656.

75. Bostman OM. Body mass index and height in patients requiring surgery for lumbar intervertebral disc herniation. Spine. 1993;18(7): 851-854.

76. Watson KD, Papageorgiou AC, Jones GT, et al. Low back pain in schoolchildren: occurrence and characteristics. Pain. 2002;97(1-2): 87-92.

77. Deere KC, Clinch J, Holliday K, et al. Obesity is a risk factor for musculoskeletal pain in adolescents: findings from a population-based cohort. Pain. 2012;153(9):1932-1938

78. Shiri R, Karppinen J, Leino-Arjas P, Solovieva S, Viikari-Juntura E. The association between obesity and low back pain: a meta-analysis. Am J Epidemiol. 2010;171(2):135-154.
79. Hershkovich O, Friedlander A, Gordon B, et al. Associations of body mass index and body height with low back pain in 829,791 adolescents. Am J Epidemiol. 2013;178(4):603-609.

80. Aro S, Leino P. Overweight and musculoskeletal morbidity: a ten-year follow up. Int J Obes. 1985;9(4):267-275.

81. Bergenudd H, Nilsson B, Udén A, Willner S. Bone mineral content, gender, body posture, and build in relation to back pain in middle age. Spine. 1989;14(6):577-579.

82. Wright C. A US epidemic: childhood obesity. J Physician Assist Educ. 2010;21(2):39-41.

83. Van Dieen JH, de Looze MP, Hermans V. Effect of dynamic office chairs on trunk kinematics, trunk extensor EMG and spinal shrinkage. Ergonomics. 2001;44(7):739-750.

84. Verni E, Prosperi L, Lucaccini C, Fedele L, Beluzzi R, Lubich T. Lumbar pain and fin swimming. J Sports Med Phys Fitness. 1999;39(1):61-65.

85. Erne C, Elfering A. Low back pain at school: unique risk deriving from unsatisfactory grade in maths and school-type recommendation. Eur Spine J. 2011;20(12):2126-2133.

86. Bjorck-van Dijken C, Fjellman-Wiklund A, Hildingsson C. Low back pain, lifestyle factors and physical activity: a population based-study. J Rehabil Med. 2008;40(10):864-869.

87. Nagasu M, Sakai K, Ito A, et al. Prevalence and risk factors for low back pain among professional cooks working in school lunch services. BMC Public Health. 2007;7:171.

88. Kujala UM, Taimela S, Viljanen T. Leisure physical activity and various pain symptoms among adolescents. Br J Sports Med. 1999;33(5):325-328.

89. Sjolie AN. Associations between activities and low back pain in adolescents. Scand J Med Sci Sports. 2004;14(6):352-359.

90. Mikkelsson LO, Nupponen H, Kaprio J, Kautiainen H, Mikkelsson M, Kujala UM. Adolescent flexibility, endurance strength, and physical activity as predictors of adult tension neck, low back pain, and knee injury: a 25-year follow up study. Br J Sports Med. 2006;40(2):107-113.

91. Aartun E, Hartvigsen J, Boyle E, Hestbaek L. No associations between objectively measured physical activity and spinal pain in 11-15-yearold Danes. Eur J Pain. 2016;20(3):447-457.

92. Troussier B, Davoine B, de Gaudemaris R, Foconni J, Phelip X. Back pain in school children. Study among 1178 people. Scand J Rehabil Med. 1994;26(3):143-146.

93. Dey M1, Jorm AF, Mackinnon AJ. Cross-sectional time trends in psychological and somatic health complaints among adolescents: a structural equation modelling analysis of 'Health Behaviour in Schoolaged Children' data from Switzerland. Soc Psychiatry Psychiatr Epidemiol. 2015;50(8):1189-1198.

94. Brun F. La lombalgie communede l'adolescent. Etude de prévalence et des facteurs associés chez 1207 lycéens [thesis]. Grenoble: Joseph Fourier University; 1998.

95. Christodoulou S, Goula T, Ververidis A, Drosos G. Vitamin D and bone disease. Biomed Res Int. 2013;2013:396541.

96. Bikle DD. Vitamin D and bone. Curr Osteoporos Rep. 2012;10(2): 151-159.

97. Pearce SH, Cheetham TD. Diagnosis and management of vitamin D deficiency. BMJ. 2010;340:b5664.

98. Ghai B, Bansal D, Kanukula R, et al. Vitamin D Supplementation in Patients with Chronic Low Back Pain: An Open Label, Single Arm Clinical Trial. Pain Physician. 2017;20(1):E99-E105.

99. Johansen JV, Manniche C, Kjaer P. Vitamin D levels appear to be normal in Danish patients attending secondary care for low back pain and a weak positive correlation between serum level Vitamin D and Modic changes was demonstrated: a cross-sectional cohort study of consecutive patients with non-specific low back pain. BMC Musculoskelet Disord. 2013;4;14:78.

100. Ghai B, Bansal D, Kapil G, Kanukula R, Lavudiya S, Sachdeva N. High prevalence of hypovitaminosis $\mathrm{D}$ in Indian chronic low back patients. Pain Physician. 2015;18(5):E853-E862.

101. Abbasi M, Hashemipour S, Hajmanuchehri F, et al. Is vitamin D deficiency associated with non- specific musculoskeletal pain? Glob J Health Sci. 2012;5(1):107-111. 
102. Matsuoka LY, Wortsman J, Dannenberg MJ, Hollis BW, Lu Z, Holick MF. Clothing prevents ultraviolet-B radiation-dependent photosynthesis of vitamin D3. J Clin Endocrinol Metab. 1992;75(4):1099-1103.

103. Islam MZ, Akhtaruzzaman M, Lamberg-Allardt C. Hypovitaminosis $\mathrm{D}$ is common in both veiled and nonveiled Bangladeshi women. Asia Pac J Clin Nutr. 2006;15(1):81-87.

104. Gannage-Yared MH, Chemali R, Yaacoub N, Halaby G. Hypovitaminosis D in a sunny country: relation to lifestyle and bone markers. J Bone Miner Res. 2000;15(9):1856-1862.

105. Moussavi M, Heidarpour R, Aminorroaya A, Pournaghshband Z, Amini M. Prevalence of vitamin D deficiency in Isfahani high school students in 2004. Horm Res. 2005;64(3):144-148.

106. Meddeb N, Sahli H, Chahed M, et al. Vitamin D deficiency in Tunisia. Osteoporos Int. 2005;16(2):180-183.

107. Sandoughi M, Zakeri Z, Mirhosainee Z, Mohammadi M, Shahbakhsh S. The effect of vitamin D on nonspecific low back pain. Int $J$ Rheum Dis. 2015;18(8):854-858.

108. Alagol F, Shihadeh Y, Boztepe H, et al. Sunlight exposure and vitamin D deficiency in Turkish women. J Endocrinol Invest. 2000;23(3): 173-177.

109. Allali F, El Aichaoui S, Khazani H. High prevalence of hypovitaminosis D in Morocco: relationship to lifestyle, physical performance, bone markers, and bone mineral density. Semin Arthritis Rheum 2009;38(6):444-451.
110. Zhang FF, Al Hooti S2, Al Zenki S, et al. Vitamin D deficiency is associated with high prevalence of diabetes in Kuwaiti adults: results from a national survey. BMC Public Health. 2016;16:100.

111. Allen D, Lamb GD, Westerblad H. Skeletal muscle fatigue: cellular mechanisms. Physiol Rev. 2008;88(1):287-332.

112. McKenna MJ, Bangsbo J, Renaud JM. Muscle $\mathrm{K}+, \mathrm{Na}+$, and $\mathrm{Cl}$ disturbances and $\mathrm{Na}+-\mathrm{K}+$ pump inactivation: implications for fatigue. J Appl Physiol. 2008;104(1):288-295.

113. Shave R, Baggish A, George K, et al. Exercise induced cardiac troponin elevation: evidence, mechanisms, and implications. J Am Coll Cardiol. 2010;56(3):169-176.

114. Mastaloudis A, Leonard SW, Traber MG. Oxidative stress in athletes during extreme endurance exercise. Free Radic Biol Med. 2001;31(7): 911-922.

115. Cazorla G, Petibois C, Bosquet L. Lactate et exercice: mythes et realites. [Lactate and exercise: myths and Realities]. Rev Sci Tech Activ Phys Sport (Grenoble). 2001;22(54):63-76. French.

116. Gordon CM, DePeter KC, Feldman HA, Grace E, Emans SJ. Prevalence of vitamin D deficiency among healthy adolescents. Arch Pediatr Adolesc Med. 2004;158(6):531-537.

117. Filteau S, Rehman AM, Yousafzai A, et al. Associations of vitamin D status, bone health and anthropometry, with gross motor development and performance of school-aged Indian children who were born at term with low birth weight. BMJ Open. 2016;8;6(1):e009268

\section{Journal of Pain Research}

\section{Publish your work in this journal}

The Journal of Pain Research is an international, peer reviewed, open access, online journal that welcomes laboratory and clinical findings in the fields of pain research and the prevention and management of pain. Original research, reviews, symposium reports, hypothesis formation and commentaries are all considered for publication.

\section{Dovepress}

The manuscript management system is completely online and includes a very quick and fair peer-review system, which is all easy to use. Visit http://www.dovepress.com/testimonials.php to read real quotes from published authors. 